\title{
Role of H1 Receptors and P-Selectin in Histamine-induced Leukocyte Rolling and Adhesion in Postcapillary Venules
}

\author{
Hiroshi Asako, Iwao Kurose, Robert Wolf, Shawn Defrees, * Zhong-Li Zheng, * M. Laurie Phillips, * \\ James C. Paulson, * and D. Neil Granger \\ Departments of Physiology and Medicine, Louisiana State University Medical Center, Shreveport, Louisiana 71130; \\ and ${ }^{*}$ Cytel Corporation, San Diego, California 92121
}

\begin{abstract}
The objective of this study was to define the nature, magnitude, and mechanisms of histamine-induced leukocyte-endothelial cell interactions in postcapillary venules of the rat mesentery using intravital microscopic techniques. Superfusion of the mesentery with histamine $\left(10^{-7}-10^{-5} \mathrm{M}\right)$ resulted in a dose-related increase in the number of rolling leukocytes, a reduction in rolling velocity, and an increased clearance of FITC-labeled rat albumin from blood to superfusate. The histamine-induced recruitment of rolling leukocytes and increased albumin clearance were prevented by histamine $\mathrm{H1}$ (hydroxyzine, diphenhydramine) but not $\mathrm{H} 2$ (cimetidine) receptor antagonists. Because histamine induces expression of the adhesion molecule P-selectin in cultured endothelial cells, a monoclonal antibody directed against rat $\mathbf{P}$-selectin and soluble sialyl-Lewis ${ }^{\mathbf{x}}$ oligosaccharide (the carbohydrate ligand to P-selectin) were also tested as inhibitors. Both were effective in preventing the histamine-induced recruitment of rolling leukocytes, but neither agent attenuated the increased albumin clearance. These observations suggest that $(a)$ histamine recruits rolling leukocytes and increases albumin leakage in postcapillary venules via $\mathrm{H1}$ receptor activation, $(b)$ histamine-induced recruitment of rolling leukocytes is mediated in part by $\mathbf{P}$-selectin expressed on the endothelial cell surface, and $(c)$ the histamine-induced vascular albumin leakage is unrelated to leukocyte-endothelial cell adhesion. Our results are consistent with the view that histamine may act as a mediator of acute inflammatory reactions. (J. Clin. Invest. 1994.93:1508-1515.) Key words: leukocyte-endothelial cell adhesion $\cdot \mathbf{P}$-selectin $\cdot$ sialyl-Lewis $\mathbf{x} \cdot$ inflammation - leukocyte rolling
\end{abstract}

\section{Introduction}

Histamine has long been implicated as a mediator of acute inflammatory reactions (1). The concept that histamine may act as an inflammatory mediator is based on several lines of evidence: $(a)$ the actions of histamine in regional vascular beds closely parallel those seen in inflammatory foci, including vasodilation, increased vascular permeability, and interstitial edema; $(b)$ histamine release has been demonstrated in a vari-

Address correspondence to D. Neil Granger, Ph.D., Department of Physiology, Louisiana State University Medical Center, 1501 Kings Highway, P.O. Box 33932, Shreveport, LA 71130-3932.

Received for publication 19 October 1993 and in revised form 15 November 1993

J. Clin. Invest.

(c) The American Society for Clinical Investigation, Inc.

0021-9738/94/04/1508/08 \$2.00

Volume 93, April 1994, 1508-1515 ety of inflammatory conditions; and $(c)$ histamine antagonists reduce the hyperemia and edema associated with early inflammation (1-5). Interest in histamine as a modulator of the inflammatory response has increased recently with the recognition that neutrophils adhere avidly to monolayers of cultured vascular endothelial cells incubated with this autacoid $(6,7)$. Histamine-induced neutrophil adhesion appears to be initiated from a rapid and transient cell-surface expression of the leukocyte adhesion molecule P-selectin (GMP-140/PADGEM) contained in secretory granules of both endothelial cells and platelets $(6,8,9)$. Despite these in vitro findings, a role for histamine in recruitment of neutrophils to sites of inflammation has not been documented in vivo.

P-selectin is one of three members of the selectin family. It is found in endothelial cells and platelets and is rapidly expressed in response to histamine $(6,10)$, thrombin, and oxygen radicals. The other two members of the family are E-selectin, which is expressed on endothelial cells in response to inflammatory cytokines and endotoxin, and L-selectin which is constitutively expressed on neutrophils and other leukocytes $(11,12)$. The selectins participate in neutrophil recruitment to sites of inflammation in a multistep process involving rolling of the neutrophils on activated endothelium, activation of the rolling cells to upregulate integrin adhesion molecules, firm adhesion of the cells to the endothelium, and transmigration through the venule wall into the tissue (13-15). Each of the three selectins has been proposed to participate in the initial rolling of leukocytes on the activated endothelium (13-15). Evidence for P-selectin-mediated rolling of leukocytes is provided by in vitro studies using artificial lipid bilayers containing P-selectin (14), immobilized platelets (16), or histaminestimulated monolayers of endothelial cells (9), all of which support rolling under flow conditions similar to those found in the microcirculation. In addition, the results of recent in vivo studies indicate that P-selectin contributes to the basal (spontaneous) leukocyte rolling observed in postcapillary venules of exteriorized mesenteric preparations $(17,18)$. However, the importance of P-selectin in mediating the recruitment of rolling leukocvtes in postcapillary venules exposed to histamine remains unclear.

The overall objective of this study was to define the ability of histamine to induce leukocyte-endothelial cell interactions in rat mesenteric venules in vivo and to evaluate the role of P-selectin in these interactions. Four specific issues were addressed: $(a)$ what are the effects of different concentrations of histamine $\left(10^{-7}-10^{-5} \mathrm{M}\right)$ on the rolling, adherence, and emigration of leukocytes and vascular albumin leakage?; $(b)$ which subtype ( $\mathrm{H} 1$ vs $\mathrm{H} 2$ ) of histamine receptors mediates the histamine-induced leukocyte-endothelial cell adhesion?; $(c)$ does P-selectin contribute to histamine-mediated leukocyte-endothelial cell interactions in vivo?; and $(d)$ is the histamine-in- 
duced increase in vascular protein leakage dependent on leukocyte adhesion?

\section{Methods}

Surgical procedure. 64 male Sprague-Dawley rats (200-250 g) were maintained on a purified laboratory diet and fasted for $24 \mathrm{~h}$ before the experiment. The animals were initially anesthetized with pentobarbital ( $65 \mathrm{mg} / \mathrm{kg}$ body wt, intraperitoneally), then a tracheotomy was performed to facilitate breathing during the experiment. The right carotid artery was cannulated, and systemic arterial pressure was measured with a pressure transducer ( $\mathrm{P} 23 \mathrm{~A}$; Statham, Oxnard, CA) connected to the carotid artery cannula. Systemic blood pressure and heart rate were continuously recorded with a physiologic recorder (Grass Instrument Co., Quincy, MA). The left jugular vein was also cannulated for drug administration and blood sample collection. After a midline abdominal incision, both renal pedicles were ligated, and a segment of the midjejunum was exteriorized. All exposed tissue was moistened with saline-soaked gauze to minimize evaporation and dehydration.

Intravital microscopy. Rats were placed in a supine position on an adjustable Plexiglas microscope stage, and the mesentery was prepared for microscopic observation as described previously $(19,20)$, with minor modifications for measurement of vascular albumin clearance. Approximately $30 \mathrm{~min}$ were required for exteriorization of the mesentery. Briefly, the mesentery was draped over an optically clear coverslip that allowed for observation of a 2-cm ${ }^{2}$ segment of tissue. The temperature of the pedestal was maintained at $37^{\circ} \mathrm{C}$ with a constant temperature circulator (model 80; Fisher Scientific Co., Pittsburgh, PA). A small rubber gasket (internal area $=3.14 \mathrm{~cm}^{2}$ ) was placed on the mesentery, and the outside area of contact between the gasket and mesentery was sealed (to prevent leakage of superfusate from the ring) with a mixture of high vacuum grease (Dow Corning Corp., Midland, MI) and white petrolatum (E. Fougera \& Co., Melville, NY). Rectal and mesenteric temperatures were continuously monitored using an electrothermometer. The exposed bowel wall was covered with Saran Wrap (The Dow Chemical Co., Indianapolis, IN), then the mesenteric tissue within the gasket was suffused with warmed bicarbonate-buffered saline $(\mathrm{BBS})^{1}(\mathrm{pH} 7.4)$ that was bubbled with a mixture of $5 \% \mathrm{O}_{2} / 5 \%$ $\mathrm{CO}_{2} / 90 \% \mathrm{~N}_{2}$.

An inverted microscope (Nikon Optiphoto, Japan) with an objective lens (magnification of 40) (Nikon Optiphoto) and an eyepiece (magnification of 10) was used to observe the mesenteric microcirculation. The mesentery was transilluminated with a $12-\mathrm{V}, 100-\mathrm{W}$ direct current-stabilized light source. A video camera (VK-C150; Hitachi Ltd., Tokyo, Japan) mounted on the microscope projected the image onto a color monitor (PVM-2030; Sony, Japan), and the images were recorded using a video cassette recorder (NV8950; Panasonic, Japan). A video time-date generator (WJ810; Panasonic) projected the time, date, and stopwatch function onto the monitor.

Single unbranched venules with diameters ranging between 25 and $35 \mu \mathrm{m}$ and a length $>150 \mu \mathrm{m}$ were selected for study. Venular diameter was measured either on- or off-line using a video image-shearing monitor (IPM, Inc., La Mesa, CA). The number of adherent leukocytes was determined off-line during playback of videotaped images. A leukocyte was considered to be adherent to venular endothelium if it remained stationary for a period $\geq 30 \mathrm{~s}$ (19). Adherent cells were expressed as the number per $100-\mu \mathrm{m}$ length of venule. The number of emigrated leukocytes was also determined off-line during playback of videotaped images. Any interstitial leukocytes present in the mesentery at the onset of the experiment were subtracted from the total number of leukocytes that accumulated during the course of the experiment. Leukocyte emigration was expressed as the number per microscopic field $\left(1.7 \times 10^{-2} \mathrm{~mm}^{2}\right.$ or $150-\mu \mathrm{m}$ length of venule). Rolling leukocytes were defined as those white blood cells that moved at a velocity less than that

1. Abbreviations used in this paper: BBS, bicarbonate-buffered saline; HUVEC, human umbilical vein endothelial cell; SLe ${ }^{\mathbf{x}}$, sialyl-Lewis ${ }^{\mathbf{x}}$. of erythrocytes in the same stream. The flux of rolling leukocytes was determined as the number of rolling leukocytes that crossed a fixed point on the venule over a given period of time. Mesenteric preparations exhibiting a basal leukocyte rolling flux $>20$ cells $/ \mathrm{min}$ were excluded from the study. Leukocyte rolling velocity was determined ( 10 cells per determination) from the time required for a leukocyte to roll along a given distance of the venule. The number of rolling leukocytes was determined from the flux of rolling leukocytes and leukocyte rolling velocity (21). Centerline red blood cell velocity was measured using an optical Doppler velocimeter (Microcirculation Research Institute, Texas A\&M University, College Station, TX) that was calibrated against a rotating glass disk coated with red blood cells. Venular blood flow was calculated from the product of mean red blood cell velocity (mean red blood cell velocity $=$ centerline velocity $\div 1.6)(22)$ and microvascular cross-sectional area, assuming cylindrical geometry. Venular wall shear rate $(\mathrm{SR})$ was calculated based on Newtonian definition: $\mathrm{SR}=8\left(V_{\text {mean }} / \mathrm{D}_{\mathrm{v}}\right)(23)$.

Albumin clearance measurements. Purified rat albumin (Sigma Chemical Co., St. Louis, MO) $(10 \mathrm{mg} / \mathrm{ml})$ was labeled with FITC (Sigma Chemical Co.) $(100 \mu \mathrm{g} / \mathrm{ml})$. FITC-labeled albumin $(100 \mathrm{mg} /$ $\mathrm{kg}$ ) was injected intravenously $24 \mathrm{~h}$ before the experiment. The vascular clearance of FITC-albumin was determined by measuring the fluorescence intensity of diluted samples of plasma and mesenteric superfusate (collected from a $3.14-\mathrm{cm}^{2}$ area) on a luminescence spectrometer (model LS-5B; Perkin-Elmer Ltd., Buckinghamshire, UK). The concentration of FITC-labeled albumin in each sample was determined from a standard curve. Vascular albumin clearance was calculated from the formula:

Albumin clearance $=\frac{\begin{array}{c}\text { superfusate FITC-albumin ] } \\ \times \text { superfusion rate }(2 \mathrm{ml} / \mathrm{min})\end{array}}{\text { [plasma FITC-albumin] }}$

Experimental protocols. After all parameters measured on-line (arterial pressure, erythrocyte velocity, and venular diameter) were in a steady state, the mesentery was superfused $(2 \mathrm{ml} / \mathrm{min})$ with either histamine $\left(10^{-7}, 10^{-6}\right.$, and $\left.10^{-5} \mathrm{M}\right)$ or BBS alone, with video recordings for quantitation of leukocyte-endothelial cell adhesion and repeat measurements of hemodynamic parameters made 20-30 min into the superfusion period. Plasma and superfusate samples were obtained at 20 min for determination of vascular albumin clearance. The responses to BBS alone or each concentration of histamine were determined in five to six rats. In some experiments, the responses to $10^{-5} \mathrm{M}$ histamine were determined in the presence of either a histamine $\mathrm{H} 1$ receptor antagonist ( $10 \mu \mathrm{M}$, hydroxyzine or diphenhydramine) or an $\mathrm{H} 2$ antagonist ( $10 \mu \mathrm{M}$, cimetidine), which was added to the superfusate. In other experiments, the responses to $10^{-5} \mathrm{M}$ histamine were examined in animals which were treated intravenously with synthetic analogues $(1 \mathrm{mg} / 100 \mathrm{~g}$ body $\mathrm{wt})$ of the carbohydrate ligand of P-selectin, sialylLewis $^{x}$ (SLe ${ }^{x}$; NeuAc $\alpha 2,3$ Gal $\beta 1,4$ [Fuc $\left.\alpha 1,3\right]$ GlcNAc-), 10 min before superfusion with histamine. The $S \mathrm{~S}^{\mathrm{x}}$ oligosaccharide used, NeuAc $\alpha 2,3 \mathrm{Gal} \beta 1,4$ (Fuc $\alpha 1,3)$ GlcNAc $\beta 1,3 \mathrm{Gal} \beta-\mathrm{O}\left(\mathrm{CH}_{2}\right)_{5} \mathrm{COOCH}_{3}$, and a control oligosaccharide missing a key fucose residue required for recognition by P-selectin, NeuAc $\alpha 2,3 \mathrm{Gal} \beta 1,4 \mathrm{GlcNAc} \beta 1,3 \mathrm{Gal} \beta$ $\mathrm{O}\left(\mathrm{CH}_{2}\right)_{5} \mathrm{COOCH}_{3}$, were prepared by a combined chemical and enzymatic strategy (24, 25, and Zheng, Z.-L., and S. DeFrees, unpublished observations). In experiments using mAbs, rats received an intravenous injection of the antibody $(2 \mathrm{mg} / \mathrm{kg}) 30 \mathrm{~min}$ before superfusion with $10^{-5} \mathrm{M}$ histamine. mAbs used included "blocking" (PB1.3; Pselectin/blocking/ $\operatorname{IgG}_{1} /$ clone 352 ) and nonblocking (PNB1.6; P-selectin/nonblocking/IgG $/$ clone P6H6) to P-selectin $(26,27)$. PB1.3 cross-reacts with rat $P$-selectin, while PNB1.6 appears not to cross-react (26). Therefore, PNB1.6 serves primarily as an isotype-matched antibody control in these experiments.

Neutrophil adhesion to cultured endothelial cells. The histamineactivated human umbilical vein endothelial cell (HUVEC) assay was performed essentially as described by Lorant et al. (15). Primary HUVEC were grown to confluence in $1 \%$ gelatin-coated (Sigma Chemical Co.) 96-well assay plates (Costar Corp., Cambridge, MA) in endothe- 
lial basal growth medium (Clonetics Corp., San Diego, CA) containing $2 \%$ human serum, $50 \mu \mathrm{g} / \mathrm{ml}$ gentamicin, $50 \mathrm{ng} / \mathrm{ml}$ amphotericin $\mathrm{B}, 1$ $\mu \mathrm{g} / \mathrm{ml}$ hydrocortisone, and $10 \%$ FCS (JRH Biosciences, Lenexa, KS) but without bovine brain extract or epithelial growth factor. The monolayers were washed $3 \times$ with $\mathrm{HBSS}$ containing $\mathrm{Ca}^{2+}$ and $\mathrm{Mg}^{2+}$ (Gibco Laboratories, Grand Island, NY), $1 \mathrm{mM}$ Hepes (Gibco Laboratories), $0.2 \% d$-glucose (Sigma Chemical Co.), and 0.5\% BSA (Sigma Chemical Co.) (HBSSg/BSA). HUVEC were activated in the same buffer for 5 min with histamine (Sigma Chemical Co.) at $10^{-4} \mathrm{M}$ for $5 \mathrm{~min}$ at $37^{\circ} \mathrm{C}$. Histamine receptor antagonists cimetidine (Sigma Chemical Co.) and diphenhydramine hydrochloride (Sigma Chemical Co.) at $10^{-5} \mathrm{M}$ were mixed with histamine before addition to the HUVEC.

Peripheral blood was obtained by venepuncture from healthy donors after informed consent according to protocols approved by the Human Subjects Review Board of Cytel Corporation. The blood was collected in syringes containing heparin $(10 \mathrm{U} / \mathrm{ml})$, and the neutrophils were isolated using Mono-poly Resolving Medium (Flow Laboratories, Inc., McLean, VA) at room temperature. Isolated neutrophils were washed $3 \times$ and resuspended in $\mathrm{HBSSg} / \mathrm{BSA}$.

After activation, the assay plate was washed $1 \times$ in $\mathrm{HBSSg} / \mathrm{BSA}$, and $100 \mu$ l of buffer containing $5 \times 10^{5}$ neutrophils was then added per well in HBSSg/BSA and allowed to settle for $5 \mathrm{~min}$. The plates were then washed by inverting and refilling with $200 \mu \mathrm{l}$ of $\mathrm{HBSSg} / \mathrm{BSA}$ using a multichannel pipette $3 \times$. Adhesion was quantitated by spectrophotometric analysis of myeloperoxidase (28).

Statistics. The data were analyzed using standard statistical analyses, i.e., ANOVA with the Scheffe's (posthoc) test. All values are reported as mean \pm SE. Statistical significance was set at $P<0.05$.

\section{Results}

Histamine-induced leukocyte rolling in mesenteric venules. The most profound effects of histamine on leukocyte-endothelial cell interactions were related to leukocyte rolling. Fig. 1 summarizes the changes in the flux of rolling leukocytes $(A)$, leukocyte rolling velocity $(B)$, and number of rolling leukocytes $(C)$ induced by different concentrations of histamine. Over the concentration range of $10^{-7}-10^{-5} \mathrm{M}$, histamine elicited a dose-related recruitment of rolling leukocytes (fivefold increase at $10^{-5} \mathrm{M}$ ) and reduced leukocyte rolling velocity $\left(50 \%\right.$ at $\left.10^{-5} \mathrm{M}\right)$. The net result of these changes was a dramatic increase in the number of rolling leukocytes in postcapillary venules at any given moment in the presence of histamine (10-fold increase at $\left.10^{-5} \mathrm{M}\right)$. We were unable to demonstrate consistently histamine-induced recruitment of rolling leukocytes when the basal flux of rolling leukocytes exceeded 20 cells/min, suggesting that the leukocyte adhesion response to histamine is more readily apparent in preparations exhibiting minimal inflammation under control conditions.

Histamine-induced leukocyte rolling and adhesion involves the $\mathrm{HI}$ receptor and P-selectin. The mechanism of histamineinduced rolling of leukocytes was investigated by examination of inhibitors of histamine receptors and known leukocyte-endothelial cell adhesion molecules. Fig. 2 shows the effect of histamine receptor antagonists on the leukocyte-rolling responses elicited by $10^{-5} \mathrm{M}$ histamine. The histamine-induced recruitment of rolling leukocytes and the reduction in leukocyterolling velocity were largely eliminated by $\mathrm{H} 1$ receptor antagonists (hydroxyzine and diphenhydramine) but not by cimetidine (an $\mathrm{H} 2$ receptor antagonist), indicating that the histamine effect is mediated predominately by the $\mathrm{H} 1$ receptor.

Since histamine is known to stimulate P-selectin-mediated adherence of neutrophils on cultured endothelial cells $(6,27)$, it was of interest to determine if this activity was an $\mathrm{H} 1$ recep-
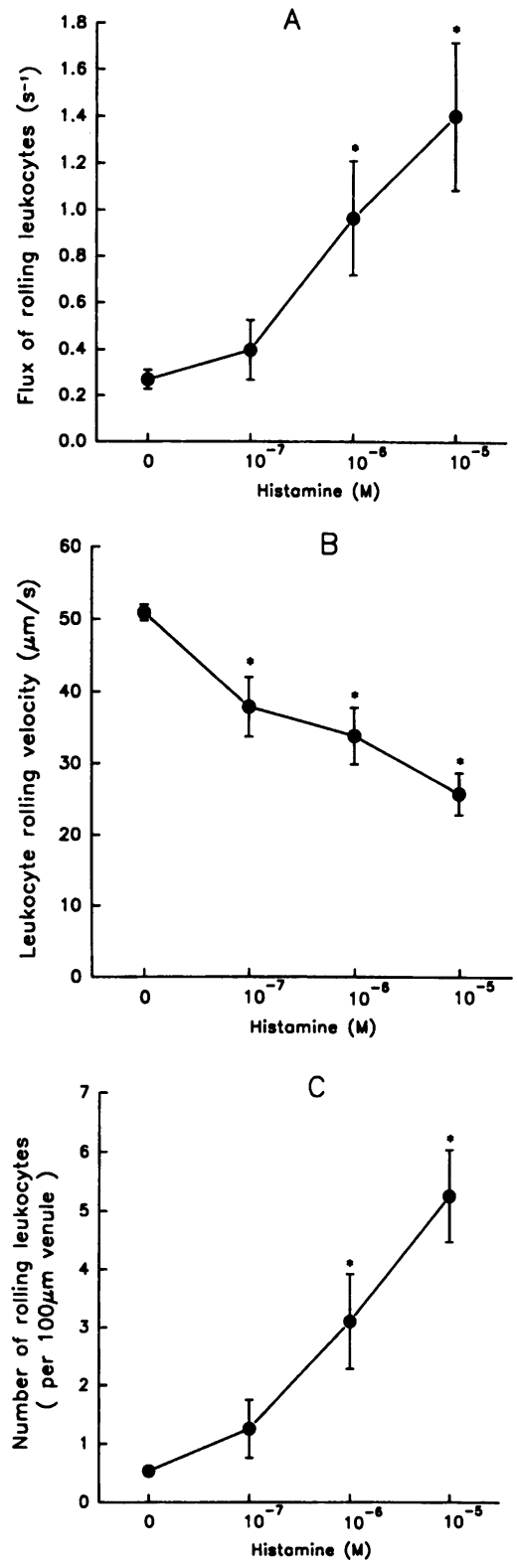

Figure 1. Induction of leukocyte rolling in mesenteric venules by histamine. Shown are the effects of increasing concentrations of histamine on the flux of rolling leukocytes $(A)$, leukocyte rolling velocity $(B)$, and number of rolling leukocytes $(C)$ in rat mesenteric venules. ${ }^{*} P<0.05$ relative to control $(0)$ value.

tor-dependent event. Indeed, as shown in Fig. 3, an $\mathrm{H} 1$ receptor antagonist (diphenhydramine), but not the $\mathrm{H} 2$ antagonist (cimetidine), abolishes histamine-induced neutrophil adhesion to cultured human umbilical cord endothelial cells.

P-selectin, which has been shown to mediate leukocyte rolling on artificial membranes and endothelial cell monolayers under shear force $(9,14)$, was therefore a prime candidate for the histamine-induced rolling of leukocytes observed in mesenteric venules. Accordingly, several P-selectin antagonists were tested for their ability to inhibit histamine-induced leukocyte rolling. As shown in Fig. 4, a blocking mAb to P-selectin (PB1.3) prevented recruitment of rolling leukocytes while a second isotype-matched nonblocking P-selectin antibody, which does not cross-react with rat P-selectin, had no effect. Similarly, a receptor antagonist based on a synthetic oligosaccharide containing the carbohydrate ligand of P-selectin SLe ${ }^{\mathrm{x}}$, NeuAc $\alpha 2,3 \mathrm{Gal} \beta 1,4$ (Fuc $\alpha 1,3)$ GlcNAc $\beta 1,3 \mathrm{Gal}-\mathrm{R}$ ), also inhibited leukocyte rolling, while a closely related inactive analogue (SLN; NeuAc $\alpha 2,3 \mathrm{Gal} \beta 1,4 \mathrm{GlcNAc} \beta 1,3 \mathrm{Gal}-\mathrm{R}$ ) had no effect. 


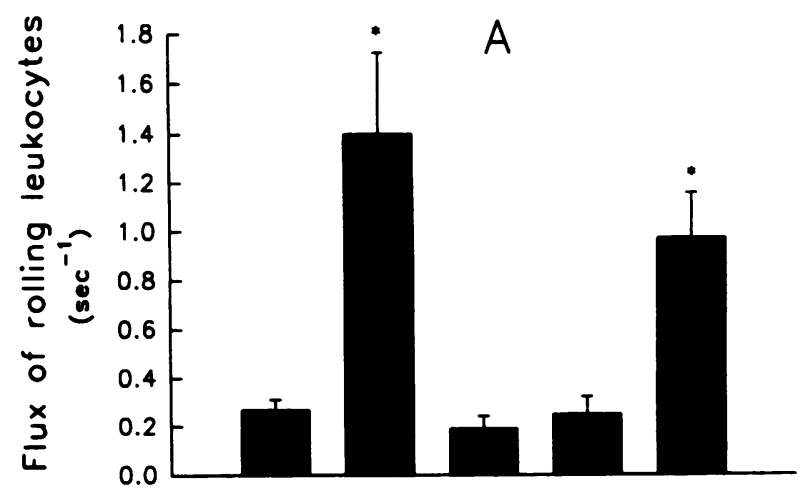

of shear rate on leukocyte rolling (29) indicate that a $40 \%$ reduction in shear rate does result in significant recruitment of rolling and adherent leukocytes. Significant increases in the number of adherent leukocytes were noted when the mesentery was superfused with histamine at concentrations of $10^{-6}$ and $10^{-5} \mathrm{M}$. The increased leukocyte adherence induced by $10^{-5} \mathrm{M}$ histamine was significantly attenuated by SLe ${ }^{\mathrm{x}}$ pentasaccharide, but not by the $\mathrm{H} 1$ and $\mathrm{H} 2$ receptor antagonists or the P-selectin mAb PB1.3.

Histamine-induced increase in vascular permeability is not dependent on leukocyte rolling. Fig. 5 illustrates the relationship between histamine concentration and vascular FITC-albumin clearance in rat mesentery. While there was a tendency for albumin clearance to increase with $10^{-6} \mathrm{M}$ histamine, a statistically significant rise (threefold) in albumin clearance was noted only at a histamine concentration of $10^{-5} \mathrm{M}$. As shown in Fig. 6, the increased vascular albumin clearance induced by $10^{-5} \mathrm{M}$ histamine was largely prevented by the $\mathrm{H} 1$ receptor antagonists (hydroxyzine and diphenhydramine) but not by the $\mathrm{H} 2$ receptor antagonist cimetidine. The histamineinduced rise in vascular protein leakage was not affected by pretreatment with either SLe ${ }^{\mathrm{x}}$ oligosaccharide or the P-selectin antibody PB1.3, both of which prevent leukocyte rolling (Fig. 4).

\section{Discussion}

Recruitment of neutrophils and resultant neutrophil-mediated pathology is an early and rate-limiting step in acute inflammation. Neutrophil recruitment is largely confined to the venous segment of the microcirculation and appears to result from several identifiable sequential steps seen as an initial rolling of the cells on the activated endothelium, activation and firm adhesion of the neutrophil, and finally trans-endothelial migration into the surrounding tissue. Increasing evidence indicates that the processes of leukocyte rolling and adhesion are coordinated by separate and distinct leukocyte adhesion molecules representing three cell-adhesion receptor families, the integrins, the immunoglobulin superfamily, and the selectins (13$15,30)$. Neutrophil adhesion and trans-endothelial migration

Figure 2. Effects of histamine $\mathrm{H} 1$ and $\mathrm{H} 2$ receptor antagonists on histamine-induced leukocyte rolling. The $\mathrm{H} 1$ receptor antagonists, hydroxyzine $(H y d)$ and diphenhydramine ( Dip ), and the $\mathrm{H} 2$ receptor antagonist, cimetidine ( $\mathrm{Cim}$ ), were evaluated for their ability to alter the flux of rolling leukocytes $(A)$, leukocyte rolling velocity $(B)$, and number of rolling leukocytes $(C)$ induced by $10^{-5} \mathrm{M}$ histamine.

Taken together, the results suggest that $\mathrm{P}$-selectin plays a major role in histamine-induced leukocyte rolling in rat mesenteric venules.

Effects of histamine on leukocyte adherence, trans-endothelial migration and hemodynamic properties. Table I summarizes the effects of histamine on the hemodynamic responses of mesenteric venules (red blood cell velocity, vessel diameter, and wall shear rate) and other changes in leukocyte-endothelial cell interactions including adherence and trans-endothelial emigration. With the exception of leukocyte adherence, histamine did not significantly alter any of the aforementioned parameters. Although there appeared to be a dose-related reduction in venular shear rate in response to histamine, this did not reach statistical significance. Previous studies of the influence

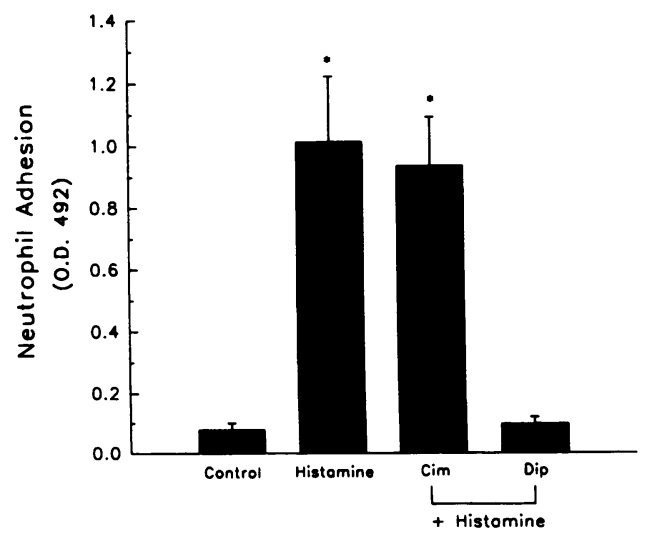

Figure 3. Effects of histamine receptor antagonists on histamine-induced adhesion of neutrophils on cultured HUVEC. The $\mathrm{H} 1$ receptor antagonist, diphenhydramine (Dip), and the $\mathrm{H} 2$ receptor antagonist, cimetidine ( $\mathrm{Cim}$ ), were evaluated for their ability to inhibit neutrophil adhesion to cultured endothelial cells induced by $10^{-4} \mathrm{M}$ histamine. 

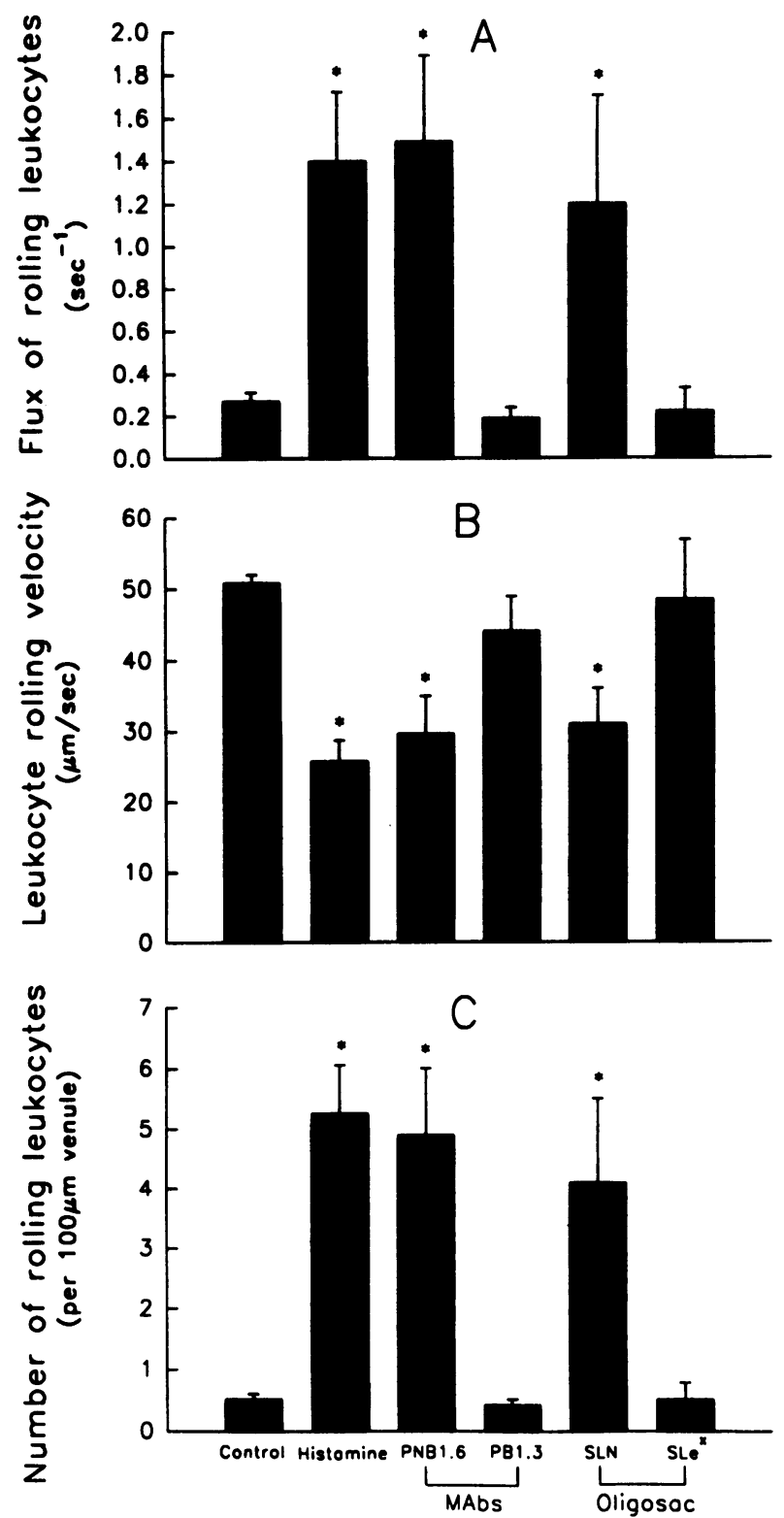

Figure 4. Effects of P-selectin antagonists on histamine-induced leukocyte rolling. Tested were a blocking mAb to P-selectin (PB1.3), a nonblocking $\mathrm{mAb}$ to $\mathrm{P}$-selectin (PNB1.6), a carbohydrate ligand receptor antagonist ( $S L e^{\mathrm{x}}$; NeuAc $\alpha 2,3 \mathrm{Gal} \beta 1,4[\mathrm{Fuc} \alpha 1,3] \mathrm{GlcNAc}$ $\mathrm{R})$, and a control oligosaccharide missing fucose ( $S L N$; NeuAc $\alpha 2,3 \mathrm{Gal} \beta 1,4 \mathrm{GlcNAc}-\mathrm{R})$. Shown is the ability of each agent to alter the flux of rolling leukocytes $(A)$, leukocyte rolling velocity $(B)$, and number of rolling leukocytes $(C)$ induced by $10^{-5} \mathrm{M}$ histamine.

are now well documented to require the interaction of the neutrophil integrins (LFA-1 and Mac-1) with their ligand, intercellular cell adhesion molecule-1 on endothelial cells $(14,30)$. It is the selectins (L-, E-, and P-selectin) which are believed to mediate the initial rolling step. L-selectin is constitutively expressed on neutrophils and is rapidly shed after neutrophil activation, while the P- and E-selectins are expressed on endothelial cells $(13,14,30)$ and recognize the $S L e^{x}$ carbohydrate ligand of glycoprotein (or glycolipid) receptor(s) on neutrophils $(11,12)$. The importance of the SLe ${ }^{x}$ ligand recognition by $E$ and P-selectins in mediating leukocyte-endothelial cell interactions has been recently confirmed by the discovery of a hu- man leukocyte adhesion deficiency resulting from the absence of SLe ${ }^{x}$ on neutrophils (31) and the demonstration that neutrophils isolated from leukocyte adhesion deficiency II patients roll poorly and fail to adhere firmly in flowing postcapillary venules of rabbit mesentery (32). Moreover, both P- and E-selectins have been implicated in leukocyte recruitment to sites of inflammation by virtue of their expression in inflammatory disease $(26,33-37)$ and by the ability of mAbs to these receptors to inhibit inflammation in animal models of disease (12, $26,38,39$ ). From a mechanistic viewpoint, there is accumulating in vivo evidence that L-selectin is required for leukocyte rolling $(13,40-42)$, however, relatively little is known about the role of $\mathrm{P}$ - and E-selectin in the modulation of leukocyteendothelial cell adhesion in inflamed postcapillary venules.

Although P- and E-selectins are both expressed on endothelial cells and bind neutrophils via $\mathrm{SLe}^{\mathrm{x}}$ glycoprotein ligands, their roles in leukocyte recruitment in vivo are differentiated by the activators of their expression. In vitro studies with cultured endothelial cells have documented that E-selectin is expressed in response to inflammatory cytokines (IL- $1 \beta$ and TNF) as well as endotoxin (12). Expression is induced by de novo synthesis requiring 2-4 $\mathrm{h}$ for accumulation of sufficient cell-surface receptor to mediate adhesion. In contrast, P-selectin expression is induced by thrombin, hydrogen peroxide, or histamine and is expressed virtually instantaneously by virtue of the fact that it is already stored presynthesized in secretory granules (Weibel-Palade bodies). With this knowledge, some predictions can be made as to the circumstances under which these two selectins will be expressed and will be available to mediate neutrophil recruitment in vivo. However, most of these activators have multiple in vivo activities, and there have been few studies which examine their effects on leukocyte-endothelial cell interactions separate from their other activities.

The contention that histamine plays a role in modulating early inflammatory responses has largely been based on reports of elevated histamine levels at sites of inflammation and the effectiveness of histamine receptor antagonists in blunting the vasodilation and interstitial edema associated with acute inflammation (1). Histamine has also been shown to exert a proinflammatory effect on isolated human granulocytes through enhancement of chemotaxis and $\mathrm{C} 3 \mathrm{~b}$ receptor (Mac1 ; CD11b/CD18) expression $(43,44)$. In general, the proinflammatory effects of histamine have been attributed to $\mathrm{H} 1$ receptor activation of leukocytes (chemotaxis) and its effects on the permeability of microvascular endothelium (1). Although several groups of investigators have reported histamineinduced enhancement of neutrophil adhesion to monolayers of cultured endothelial cells $(6,7,15)$, the consequences of such expression have not been evaluated in vivo.

In this study, we undertook a series of experiments that were designed to define the ability of histamine to induce in vivo leukocyte-endothelial cell adhesion in rat mesenteric venules. The results of our study demonstrate that histamine, over a concentration range of $10^{-5}-10^{-7} \mathrm{M}$, elicits a dose-dependent recruitment of rolling leukocytes and a reduction in leukocyte rolling velocity. Exposure of the mesenteric microcirculation to histamine did not lead to significant alterations in venular hemodynamics (e.g., wall shear rate), which indicates that the recruitment of rolling and adherent leukocytes induced by this autacoid cannot be attributed simply to shear rate-dependent leukocyte adhesion $(29,45)$. The results also demonstrate that $\mathrm{H} 1$ but not $\mathrm{H} 2$ receptor antagonists can abol- 
Table I. Effects of Histamine on Venular Hemodynamics and Leukocyte-Endothelial Cell Adhesion in the Absence or Presence of Either Hydroxyzine (Hyd), Diphenhydramine (Dip), Cimetidine (Cim), SLe $e^{x}$ Pentasaccharide (SLe $)^{x}$, Control Oligosaccharide (SLN), P-Selectin Antibody (mAb PB1.3), or an Isotype-matched Antibody Control (mAb PNB1.6)

\begin{tabular}{|c|c|c|c|c|c|}
\hline & $\begin{array}{l}\text { Leukocyte } \\
\text { adherence } \\
\text { per } 100 \mu \mathrm{m}\end{array}$ & $\begin{array}{c}\text { Leukocyte } \\
\text { emigration } \\
\text { per field }\end{array}$ & $\begin{array}{l}\text { Erythrocyte } \\
\text { velocity }\end{array}$ & $\begin{array}{c}\text { Venular } \\
\text { diameter }\end{array}$ & $\begin{array}{c}\text { Wall } \\
\text { shear rate }\end{array}$ \\
\hline & & & $\mathrm{mm} / \mathrm{s}$ & $\mu m$ & $s^{-1}$ \\
\hline Control & $1.0 \pm 0.6$ & $3.0 \pm 1.7$ & $2.8 \pm 0.6$ & $28 \pm 2$ & $497 \pm 81$ \\
\hline \multicolumn{6}{|l|}{ Histamine } \\
\hline $10^{-7} \mathrm{M}$ & $2.8 \pm 0.7$ & $1.5 \pm 0.7$ & $2.8 \pm 0.2$ & $30 \pm 1$ & $476 \pm 38$ \\
\hline $10^{-6} \mathrm{M}$ & $4.8 \pm 0.7^{*}$ & $2.0 \pm 0.7$ & $2.4 \pm 0.2$ & $30 \pm 1$ & $401 \pm 91$ \\
\hline $10^{-5} \mathrm{M}$ & $7.2 \pm 1.1^{*}$ & $2.5 \pm 0.9$ & $1.8 \pm 0.4$ & $30 \pm 1$ & $303 \pm 64$ \\
\hline \multicolumn{6}{|l|}{ Histamine $\left(10^{-5} \mathrm{M}\right)$} \\
\hline plus Hyd & $7.3 \pm 2.4$ & $2.3 \pm 0.3$ & $2.4 \pm 1.1$ & $28 \pm 1$ & $429 \pm 198$ \\
\hline plus Dip & $4.8 \pm 1.4$ & $2.3 \pm 1.4$ & $2.3 \pm 0.3$ & $27 \pm 1$ & $423 \pm 62$ \\
\hline plus Cim & $5.5 \pm 1.7$ & $0.5 \pm 0.3$ & $1.5 \pm 0.4$ & $28 \pm 1$ & $273 \pm 61$ \\
\hline plus SLe ${ }^{x}$ & $2.3 \pm 1.9^{\ddagger}$ & $2.0 \pm 1.2$ & $2.1 \pm 0.2$ & $29 \pm 2$ & $355 \pm 14$ \\
\hline plus SLN & $5.5 \pm 1.4$ & $4.8 \pm 2.8$ & $3.0 \pm 0.5$ & $31 \pm 2$ & $495 \pm 28$ \\
\hline plus mAb PB1.3 & $4.5 \pm 2.1$ & $4.0 \pm 1.6$ & $2.5 \pm 1.0$ & $31 \pm 1$ & $392 \pm 146$ \\
\hline plus mAb PNB1.6 & $9.0 \pm 3.0$ & $5.0 \pm 2.0$ & $2.2 \pm 0.2$ & $29 \pm 3$ & $488 \pm 41$ \\
\hline
\end{tabular}

${ }^{*} P<0.05$ relative to control; ${ }^{\ddagger} P<0.05$ relative to $10^{-5} \mathrm{M}$ of histamine.

ish the recruitment of rolling leukocytes and the reduction in leukocyte rolling velocity induced by histamine. This provides additional evidence for the importance of $\mathrm{H} 1$ receptor stimulation in the inflammatory responses mediated by histamine.

Histamine also induced a dose-dependent increase in the number of adherent neutrophils as defined by cells which remained stationary cells for at least $30 \mathrm{~s}$. However, most of these cells eventually were released into the circulation and did not emigrate into the surrounding tissue (Table I). The results suggest that histamine alone cannot mediate recruitment of neutrophils into inflamed tissues unless other chemical mediators are present as chemoattractants to stimulate the neutrophils to cross the venular endothelium. This is not surprising if the primary effect of histamine is to induce P-selectin, since in vitro studies have shown that interaction of neutrophils with P-selectin is not sufficient to upregulate the neutrophil integrins (LFA-1, Mac-1) required for firm adherence (14). Indeed, von Andrian et al. (42) have shown that leukocyte rolling induced in rabbit mesenteric venules by IL- $1 \beta$ (which upregulates E-selectin) does not lead to firm adhesion and emigration unless the neutrophil activator leukotriene $\mathrm{B}_{4}\left(\mathrm{LTB}_{4}\right)$ is added to the superfusate. The results emphasize that leukocyte rolling

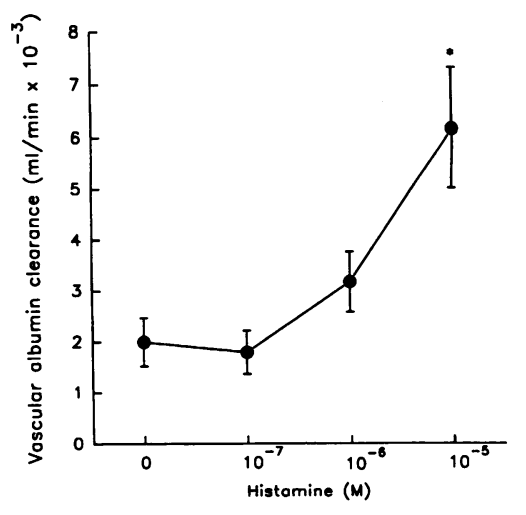

Figure 5. Influence of histamine on vascular clearance of FITC-labeled rat albumin. Different concentrations of histamine were evaluated for their ability to increase clearance of FITC-labeled albumin. ${ }^{*} P<0.05$ relative to control value. is only a prerequisite to the movement of neutrophils from the blood to the extravascular sites; it is not a committed step.

One of the major objectives of this study was to assess whether P-selectin contributes to histamine-mediated leukocyte adhesion in vivo. Two experimental approaches were used to address this issue: $(a)$ immunoneutralization of P-selectin with a specific $\mathrm{mAb}$, and $(b)$ functional inactivation of P-selectin by administration of a soluble form of a carbohydrate component $\left(\mathrm{SLe}^{\mathrm{x}}\right)$ of its putative ligand on endothelial cells. Our results indicate that intravascular administration of either a monoclonal antibody directed against P-selectin or the SLe ${ }^{\mathrm{x}}$ oligosaccharide effectively prevents the recruitment of rolling

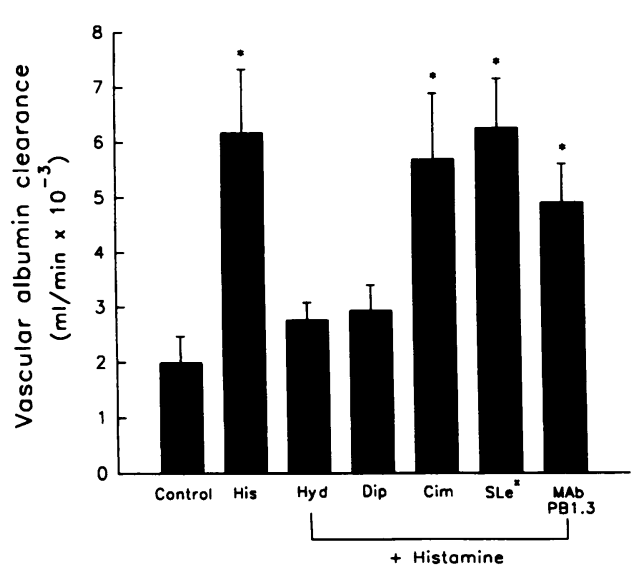

Figure 6. Effects of histamine receptor antagonists and P-selectin antagonists on vascular albumin clearance. The histamine $\mathrm{H} 1$ receptor antagonists, hydroxyzine $(H y d)$, diphenhydramine (Dip), the histamine $\mathrm{H} 2$ receptor antagonist cimetidine $(\mathrm{Cim})$, the blocking P-selectin mAb PB1.3, and the SLe ${ }^{x}$ carbohydrate blocker of P-selectin were evaluated for their ability to inhibit the increased vascular clearance of FITC-labeled albumin induced by $10^{-5} \mathrm{M}$ histamine. ${ }^{*} P<0.05$ relative to control value. 
leukocytes and reduction in leukocyte rolling velocity elicited in postcapillary venules by histamine. These observations provide evidence that expression of P-selectin on microvascular endothelium is a prerequisite for histamine-mediated leukocyte rolling and that histamine presumably stimulates leukocyte rolling via $\mathrm{H} 1$ receptor-induced $\mathrm{P}$-selectin mobilization from Weibel-Palade bodies (46) to the endothelial cell surface. The observation that the SLe ${ }^{x}$ oligosaccharide was as effective as the $\mathrm{P}$-selectin antibody in abolishing histamine-induced leukocyte rolling supports the view that $\mathrm{SLe}^{\mathrm{x}}$ is an inhibitor of P-selectin. Nonetheless, P-, E-, and L-selectin all bind with varying degrees of affinity to the oligosaccharide (47). Consequently, we cannot rule out the possibility that the profound attenuation of histamine-induced leukocyte rolling associated with SLe ${ }^{x}$ oligosaccharide administration reflects an inhibition of all selectins that are likely to be expressed/activated during the period of histamine exposure, i.e., P- and L-selectin.

A well characterized biological action of histamine is the formation of large interendothelial cell gaps in postcapillary venules with a resultant increase in vascular protein leakage (1-3). In some vascular beds, the histamine influence on venular permeability is mediated through stimulation of $\mathrm{H} 2$ receptors (3), however, in the majority of tissues studied, histamineinduced increases in vascular permeability is largely $\mathrm{H} 1$ mediated (1). The results of our studies also indicate a dominant influence of $\mathrm{H} 1$ receptors in the increased vascular permeability induced by histamine in rat mesentery. Inasmuch as $\mathrm{H} 1$ receptor antagonists were effective in blocking both the increased vascular protein leakage and leukocyte-endothelial cell adhesion elicited by histamine, a question arises concerning the possible link between $\mathrm{H} 1$-mediated leukocyte adhesion and increased protein leakage in postcapillary venules, i.e., is the histamine-induced increase in vascular protein leakage dependent on leukocyte adhesion? Our observation that the rise in vascular protein leakage was unaffected by agents which completely inhibit histamine-induced leukocyte-endothelial cell adhesion (P-selectin antibody, SLe ${ }^{\mathrm{x}}$ oligosaccharide) bears directly on this issue. This finding would argue against a primary role for leukocyte adhesion (rolling) in mediating the histamine-induced microvascular dysfunction and it is consistent with the view that histamine elicits the contraction of endothelial actin-myosin filaments in postcapillary venules, which leads to the formation of intercellular gaps (5). A dissociation between the vascular permeability changes and leukocyte adhesion induced by histamine is also supported by previous studies which demonstrate that neutropenia is associated with a significant reduction in the microvascular leakage normally elicited by $\mathrm{LTB}_{4}$, whereas the response to histamine is not affected (48). Our previous studies on the relationship between leukocyte-endothelial cell adhesion and vascular protein leakage induced by platelet-activating factor or $\mathrm{LTB}_{4}$ suggests that adhesion-dependent neutrophil functions such as emigration and oxidant production play a more important role than leukocyte adherence or rolling per se in producing the alterations in vascular integrity observed in inflamed microvessels (49).

In conclusion, the results of this study indicate that histamine promotes leukocyte rolling in postcapillary venules through engagement of $\mathrm{H} 1$ receptors, presumably located on endothelial cells. The proadhesive effects of histamine appear to be largely mediated by an interaction between P-selectin on endothelial cells and a ligand containing $S L e^{x}$ on leukocytes. The vascular protein leakage induced by histamine is also me- diated by $\mathrm{H} 1$ receptors, but is unrelated to the leukocyte-endothelial cell adhesion. These observations provide a basis for the widely held view that histamine plays an important role in the early events associated with an inflammatory response.

\section{Acknowledgments}

We thank Bill Way for technical assistance, Bob Bayer for communicating unpublished results, and Anggie Becorest, Federico Gaeta, Yukishige Ito, Diane LaPointe, Murray Ratcliffe, Les Walker, and Mark Williams for preparation and characterization of the reagents used in this report.

This study was supported by a grant from the National Institute of Diabetes and Digestive and Kidney Diseases (DK 43785).

\section{References}

1. White, M. V., and M. A. Kaliner. 1988. Histamine. In Inflammation: Basic Principles and Clinical Correlations. J. I. Gallin, I. M. Goldstein, and R. Snyderman, editors. Raven Press, New York. 169-187.

2. Falus, A., and K. Meretey. 1992. Histamine: an early messenger in inflammatory and immune reactions. Immunol. Today. 13:154-156.

3. Mortillaro, N. A., D. N. Granger, P. R. Kvietys, G. Rutili, and A. E. Taylor. 1981. Effects of histamine and histamine antagonists on intestinal capillary permeability. Am. J. Physiol. 240:G381-G386.

4. Issekutz, A. C. 1981. Effect of vasoactive agents on polymorphonuclear leukocyte emigration in vivo. Lab. Invest. 45:234-240.

5. Paterson, I. S., J. M. Klausner, G. Goldman, R. Welbourn, J. S. Alexander, D. Shepro, and H. B. Hechtman. 1989. The endothelial cell cytoskeleton modulates extravascular polymorphonuclear leukocyte accumulation in vivo. Microvasc. Res. 38:49-56.

6. Geng, J. G., M. P. Bevilacqua, K. L. Moore, T. M. McIntyre, S. M. Prescott, J. M. Kim, G. A. Bliss, G. A. Zimmerman, and R. P. McEver. 1990. Rapid neutrophil adhesion to activated endothelium mediated by GMP-140. Nature (Lond.). 343:757-760.

7. Watanabe, M., M. Yagi, M. Omata, N. Hirasawa, S. Mue, S. Tsurufuji, and K. Ohuchi. 1990. Stimulation of neutrophil adherence to vascular endothelial cells by histamine and thrombin and its inhibition by PAF antagonists and dexamethasone. Br. J. Pharmacol. 102:239-245.

8. Larsen, E., A. Celi, G. E. Gilbert, B. C. Furie, J. K. Erban, R. Bonfanti, D. D. Wagner, and B. Furie. 1989. PADGEM protein: a receptor that mediates the interaction of activated platelets with neutrophils and monocytes. Cell. 59:305-312.

9. Jones, D. A., O. Abbassi, L. V. McIntire, R. P. McEver, and C. W. Smith. 1993. P-selectin mediates neutrophil rolling on histamine-stimulated endothelial cells. Biophys. J. 65:1560-1569.

10. Patel, K. D., G. A. Zimmerman, S. M. Prescott, R. P. McEver, and T. M. McIntyre. 1991. Oxygen radicals induce human endothelial cells to express GMP-140 and bind neutrophils. J. Cell Biol. 112:749-759.

11. Springer, T. A., and L. A. Lasky. 1991. Sticky sugars for selectins. Nature (Lond.). 349:196-197.

12. Paulson, J. C. 1992. Selectin/carbohydrate-mediated adhesion of leukocytes. In Adhesion: Its Role in Inflammatory Disease. J. M. Harlan and D. Y. Liu, editors. W. H. Freeman \& Co., New York. 19-42.

13. Butcher, D. C. 1991. Leukocyte-endothelial cell recognition: three (or more) steps to specificity and diversity. Cell. 67:1033-1036.

14. Lawrence, M. B., and T. A. Springer. 1991. Leukocyte roll on a selectin at physiologic flow rates: Distinction from and prerequisite for adhesion through integrins. Cell. 65:859-873.

15. Lorant, D. E., K. D. Patel, T. M. McIntyre, R. P. McEver, S. M. Prescott, and G. A. Zimmerman. 1991. Coexpression of GMP-140 and PAF by endothelium stimulated by histamine or thrombin. A juxtacrine system for adhesion and activation of neutrophils. J. Cell Biol. 115:223-234.

16. Buttrum, S. M., R. Hatton, and G. B. Nash. 1993. Selectin-mediated rolling of neutrophils on immobilized platelets. Blood. 82:1165-1174.

17. Mayadas, T. N., R. C. Johnson, H. Rayburn, R. O. Hynes, and D. D. Wagner. 1993. Leukocyte rolling and extravasation are severely compromised in P-selectin deficient mice. Cell. 74:541-554.

18. Dore, M., R. J. Korthuis, D. N. Granger, M. L. Entman, and C. W. Smith. 1993. P-selectin mediates spontaneous leukocyte rolling in vivo. Blood. 82:13081316.

19. Granger, D. N., J. N. Benoit, M. Suzuki, and M. B. Grisham. 1989. Leukocyte adherence to venular endothelium during ischemia-reperfusion. Am. J. Physiol. 257:G683-G688.

20. Asako, H., P. Kubes, B. A. Baethge, R. E. Wolf, and D. N. Granger. 1992. 
Colchicine and methotrexate reduce leukocyte adherence and emigration in rat mesenteric venules. Inflammation. 16:45-56.

21. Firrel, J. C., and H. H. Lipowsky. 1989. Leukocyte margination and deformation in mesenteric venules of rat. Am. J. Physiol. 256:H1667-H1674.

22. Davis, M. J. 1987. Determination of volumetric flow in capillary tubes using an optical Doppler velocimeter. Microvasc. Res. 34:223-230.

23. House, S. D., and H. Lipowsky. 1987. Leukocyte-endothelium adhesion: microdynamics in mesentery of the cat. Microvasc. Res. 34:363-379.

24. Ichikawa, Y., Y.-C. Lin, D. P. Dumas, G.-J. Shen, E. Garcia-Junceda, M. A. Williams, R. Bayer, C. Ketcham, L. E. Walker, J. C. Paulson, and C.-H Wong. 1992. Chemical-enzymatic synthesis and conformational analysis of sialyl Lewis $\mathrm{X}$ and derivatives. J. Am. Chem. Soc. 114:9283-9298.

25. Ball, G. E., R. A. O'Neill, J. E. Schultz, J. B. Lowe, B. W. Weston, J. O Nagy, E. G. Brown, C. J. Hobbs, and M. D. Bednarski. 1992. Synthesis and structural analysis using 2-D NMR of sialyl Lewis $X\left(S_{L} e^{x}\right)$ and Lewis $X\left(L^{x}\right)$ oligosaccharides: ligands related to E-selectin (ELAM-1) binding. J. Am. Chem. Soc. 114:5449-5451

26. Mulligan, M. S., M. J. Polley, R. J. Bayer, M. F. Nunn, J. C. Paulson, and P. A. Ward. 1992. Neutrophil-dependent acute lung injury. Requirement for P-selectin (GMP-140). J. Clin. Invest. 90:1600-1607.

27. Phillips, M. L., E. Nudelman, F. C. A. Gaeta, M. Perez, A. K. Singhal, S.-I. Hakomori, and J. C. Paulson. 1990. ELAM-1 mediates cell adhesion by recognition of a carbohydrate ligand, sialyl Lewis X. Science (Wash. DC). 250:11301132 .

28. Fernsten, P. D., K. W. Pekny, R. A. Reisfeld, and L. E. Walker. 1986 Antigens associated with human squamous cell lung carcinoma defined by murine monoclonal antibodies. Cancer Res. 46:2970-2977.

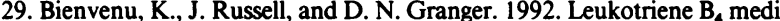
ates shear rate-dependent leukocyte adhesion in mesenteric venules. Circ. Res. 71:906-911.

30. Smith, C. W. 1992. Transendothelial migration. In Adhesion: Its Role in Inflammatory Disease. J. M. Harlan and D. Y. Liu, editors. W. H. Freeman \& Co., New York. 83-115.

31. Etzioni, A., M. Frydman, S. Pollack, I. Avidor, M. L. Phillips, J. C. Paulson, and R. Gershoni-Baruch. 1992. Recurrent, severe infections caused by a novel leukocyte adhesion deficiency. N. Engl. J. Med. 327:1789-1792.

32. von Andrian, U. H., E. M. Berger, L. Ramezani, J. D. Chambers, H. D. Ochs, J. M. Harlan, J. C. Paulson, A. Etzioni, and K.-E. Arfors. 1993. In vivo behavior of neutrophils from two patients with distinct inherited leukocyte adhesion deficiency syndromes. J. Clin. Invest. 91:2893-2897.

33. Rohde, D., W. Schlüter-Wigger, V. Mielke, P. von den Driesch, B. von Gaudecker, and W. Sterry. 1992. Infiltration of both T cells and neutrophils in the skin is accompanied by the expression of endothelial leukocyte adhesion molecule-1 (ELAM-1): an immunohistochemical and ultrastructural study. $J$. Invest. Dermatol. 98:794-799.

34. Munro, J. M. J. S. Pober, and R. S. Cotran. 1991. Recruitment of neutrophils in the local endotoxin response: association with de novo endothelial expression of endothelial leukocyte adhesion molecule-1. Lab. Invest. 64:295-299.

35. Kyan-Aung, U., D. O. Haskard, R. N. Poston, M. H. Thornhill, and T. H. Lee. 1991. Endothelial leukocyte adhesion molecule-1 and intercellular adhesion molecule-1 mediate the adhesion of eosinophils to endothelial cells in vitro and are expressed by endothelium in allergic cutaneous inflammation in vivo. J. Immunol. 146:521-528.

36. Leung, D. Y. M., J. S. Pober, and R. S. Cotran. 1991. Expression of endothelial-leukocyte adhesion molecule-1 in elicited late phase allergic reactions. J. Clin. Invest. 87:1805-1809.

37. Koch, A. E., J. C. Burrows, G. K. Haines, T. M. Carlos, J. M. Harlan, and S. J. Leibovich. 1991. Immunolocalization of endothelial and leukocyte adhesion molecules in human rheumatoid and osteoarthritic synovial tissue. Lab. Invest. 64:313-320.

38. Gundel, R. H., C. D. Wegner, C. A. Torcellini, C. C. Clarke, N. Haynes, R. Rothlein, C. W. Smith, and L. G. Letts. 1991. Endothelial leukocyte adhesion molecule-1 mediates antigen-induced acute airway inflammation and late-phase airway obstruction in monkeys. J. Clin. Invest. 88:1407-1411.

39. Mulligan, M. S., J. Varani, M. K. Dame, C. L. Lane, C. W. Smith, D. C. Anderson, and P. A. Ward. 1991. Role of endothelial-leukocyte adhesion molecule 1 (ELAM-1) in neutrophil-mediated lung injury in rats. J. Clin. Invest. 88:1396-1406.

40. von Andrian, U. H., J. D. Chambers, L. M. McEvoy, R. F. Bargatze, K. E. Arfors, and E. C. Butcher. 1991. Two-step model of leukocyte-endothelial cell interaction in inflammation: distinct roles for LECAM- 1 and the leukocyte $\beta_{2}$ integrins in vivo. Proc. Natl. Acad. Sci. USA. 88:7538-7542.

41. Ley, K., P. Gaethgens, C. Fennie, M. S. Singer, L. A. Lasky, and S. D. Rosen. 1991. LEC-CAM 1 mediates leukocyte rolling in mesenteric venules in vivo. Blood. 77:2553-2555.

42. von Andrian, U. H., P. Hansell, J. D. Chambers, E. M. Berger, I. T. Filho, E. C. Butcher, and K. E. Arfors. 1992. L-selectin function in vivo: prerequisite for $\beta 2$ integrin-mediated neutrophil adhesion at physiologic shear rates. Am. J. Physiol. (Heart/Circ.). 32:H1034-H1044.

43. Anwar, A. R. E., and A. B. Kay. 1978. Enhancement of human eosinophil complement receptors by pharmacological mediators. J. Immunol. 121:12451250

44. Anwar, A. R. E., and A. B. Kay. 1980. H1-receptor dependence of histamine-induced enhancement of human eosinophil C3b rosettes. Clin. Exp. Immunol. 42:196-199.

45. Perry, M. A., and D. N. Granger. 1991. Role of CD11/CD18 in shear rate-dependent leukocyte-endothelial cell interactions in cat mesenteric venules. J. Clin. Invest. 87:1798-1804.

46. McEver, R. P., J. H. Beckstead, K. L. Moore, L. Marshall-Carlson, and D. F. Bainton. 1989. GMP-140, a platelet $\alpha$-granule membrane protein, is also synthesized by vascular endothelial cells and is localized in Weibel-Palade bodies. $J$. Clin. Invest. 84:92-99.

47. Foxall, C., S. R. Watson, D. Dowbenko, C. Fennie, L. A. Lasky, M. Kiso, A. Hasegawa, D. Asa, and B. R. Brandley. 1992. The three members of the selectin receptor family recognize a common carbohydrate epitope, the sialyl Lewis ${ }^{\star}$ oligosaccharide. J. Cell Biol. 117:895-902.

48. Bjork, J., P. Hedqvist, and K. E. Arfors. 1982. Increase in vascular permeability induced by leukotriene $\mathrm{B}_{4}$ and the role of polymorphonuclear leukocytes. Inflammation. 6:189-200.

49. Kubes, P., M. B. Grisham, J. A. Barrowman, T. Gaginella, and D. N. Granger. 1991. Leukocyte-induced vascular protein leakage in cat mesentery. Am. J. Physiol. 261:H1872-1879. 